\title{
Indigenous plants used by the Otuo tribe of Owan East Local Government Area, Edo State, Nigeria
}

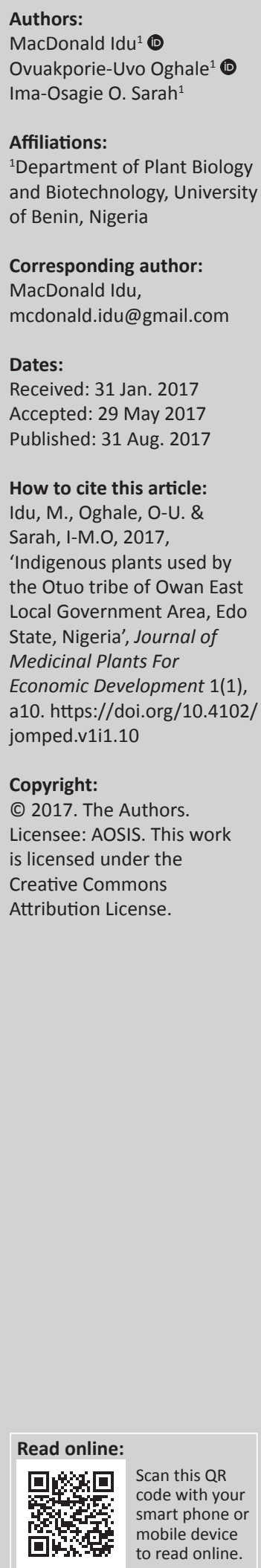

Background: Traditional medicine remains an integral part of the Otuo tribe in Owan East Local Government Area of Edo State.

Aim: The study is aimed at documenting the ethnobotany of the Otuo tribe by evaluating the uses of plants found in the area, identifying the importance value (IV), fidelity level (FL) and principal taxonomic groups of the plants.

Methods: Data were gathered following an oral interview of unlettered herbal practitioners. Literate men, women and young settlers in the community were cross-examined using a semistructured questionnaire. Fifty respondents made up this study size. Data were collated to report botanical names, common and vernacular names of the species of plants surveyed. Information on the use, methods of preparation and plant part used was documented. The FL and IV were determined.

Results: 101 plants belonging to 46 families were reported. The best-represented family was the Fabaceae with 11 species followed by the Euphorbiaceae with 6 species. Of the 101 plants, 80 plants have medicinal uses and 58 have other economic uses. Amongst the medicinal plants, Azadirachta indica had the highest FL and IV of 100 and 1.0, respectively, followed by Cymbopogon citratus with FL of 96; both plants are used to treat malaria. The major ailments treated with plants by the Otuo tribe include malaria, cataracts, rheumatism and dysentery, amongst others.

Conclusion: The people of Otuo are rich in plant-based remedies. They devotedly practise local medicine use because it is cost-effective and efficient, thereby contributing greatly to the economic development of the area.

\section{Introduction}

Ethnobotany is an aspect of plant science that deals with the general use of plants in a particular environment or society (Sofowora 1982). It studies the relationship between man, plant and the various roles plants play in the environment and what meanings society or the environment give to them. Plant use is unique to different areas of the world, and some of these plants have specific and special purposes. The plants used by any tribe or region may include drug plants, food plants, ceremonial plants, etc. Ethnobotany was historically practised by explorers who recorded the use of plants by the natives of an area in their travels. The historical knowledge of these plants was largely based on casual observations and use record, which formed the basis of today's knowledge of plant usage (Cotton 1996). Various disciplines have emerged from the field of ethnobotany, and one of such is ethnomedicine.

Ethnomedicine is the use of plants by members of an indigenous culture for which there is no organised medical system or formal training by the prescriber. In the traditional African healing system, ethnomedicine is also referred to as folk medicine, herbal medicine and native medicine. According to the World Conservation Union (WCN), approximately one-quarter of all prescription drugs are derived from plants and many of these come from the humid tropical forests (Oseni 1989). The plant parts used in ethnomedicine include the roots, leaves, bark, twigs, flowers and seeds. Plants are either used fresh or dry mostly in the form of decoction. Generally, more than one species of plant are used in preparation of the decoction. Some traditional medicines are of pharmaceutical value, while others combine the pharmaceutical with supernatural powers.

Traditional medicine is an integral part of the people who practise it. An indication of the strength of the traditional (indigenous) culture is seen because a large number of herbalists still practise and heal different ailments with herbal remedies. Although some of the practices involve rituals 
and superstition, most of the remedies are based on rather simple preparation and application of plants commonly found in the area. The insight of these medical remedies is jealously guarded and controlled by a few individuals, many of whom are elders and they are respected by the inhabitants of the area. Many of the people have used herbal remedies. The people of Otuo continue to use herbal remedies because they are cheaper, easily available and have produced positive results when used in time past.

In Nigeria, traditional medicine is used to treat a host of health conditions such as mental disorders, fractures, insomnia and infertility (Enwereji 1999). Notable contributions towards Nigerian medicinal plants have been made by Ainslie (Ainslie 1937), who was the first to list plants used in native medicine in Nigeria (Akpata 1979; Ayensu 1978; Gill 1992; Gill \& Opara 1988; Idu \& Olorunfemi 2000; Idu \& Omoruyi 2003; Lambo 1979; Mume 1976; Sofowora 1986, 1993).The knowledge and utilisation of folk medicine by aboriginal cultures are useful for conservation of cultural traditions and biodiversity and for community healthcare and drug discovery in the present and future. Thus, traditional medicine should not be considered as a system of old, but as a heritage that needs refinement and development. This study is aimed at exploring and documenting the ethnobotany of the Otuo tribe.

\section{Materials and methods The study area}

Otuo is one of the major towns in Owan East Local Government Area of Edo State, Nigeria. It is located on latitude 7.00691 and longitude 6.00522 with postcode (ZIP): 313107. It had an area of $1240 \mathrm{~km}^{2}$ and a population of 154385 persons as at the 2006 census. Owan East is boarded by Akoko Edo in the north, Etsako West Local Government Area in the east, Ekiti State in the west, Owan-West in the southwest and Esan Central/Uhunmwonde Local Government Area in the south (Figure 1). The local government comprises eight clans: Emai clan, Igue clan, Ihievbe clan, Ikao clan, IvbiMion clan, Ivia-Ada-Obi clan, Otuo clan and Uokha clan.

Otuo is surrounded by a mountainous terrain with a climate comparable to that of a rainforest zone which promotes the growth and development of a rich biodiversity. The natives are mainly involved in agriculture, weaving, pottery and blacksmithing. The major agricultural products are yam and cocoa. The majority of the plants found here have botanical and medicinal properties.

\section{Field methods}

The field trip was done in February 2016. The ethnobotanical data were collected through oral interviews of the herbal practitioners, men, women and young settlers in the community using a semi-structured questionnaire. The respondents were followed into the bush for identification and collection of plant parts. The total number of respondents was 50 , consisting of 46 men and 4 women. Data were

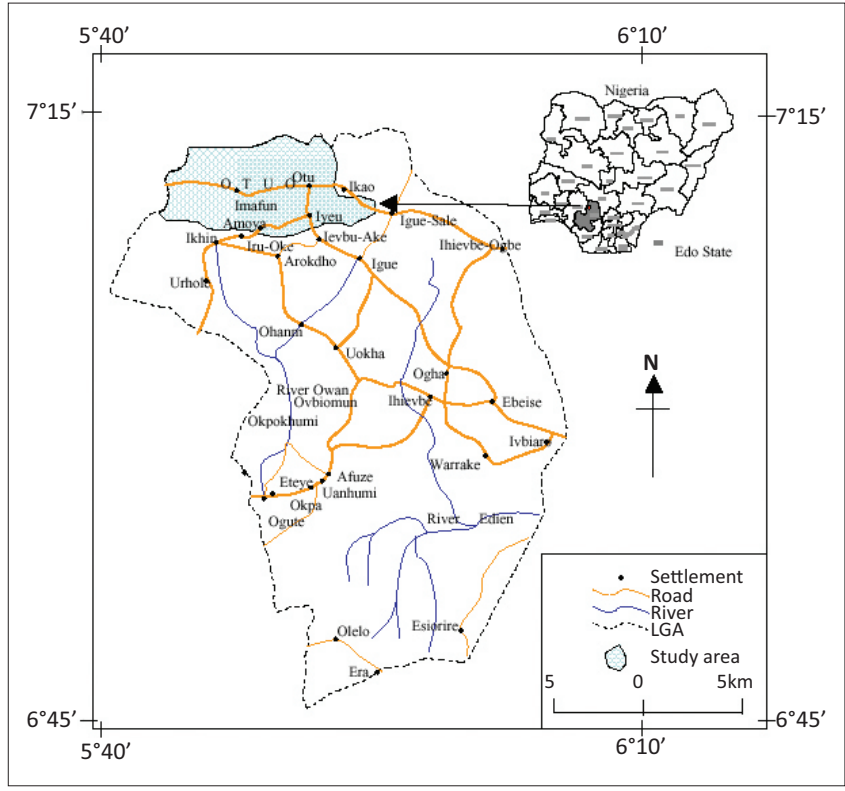

FIGURE 1: Map of Owan East Local Government Area showing the study area.

collated to give the botanical names, common names and local names of the various plant species. Information about their use, method of preparation and specific plant part used was also recorded.

The assistance of some natives of the clan coupled with the offer of cash incentive facilitated the ease with which the informants divulged their ethnobotanical and ethnomedicinal knowledge. Interviews were documented with photos of the plants.

\section{Species identification}

Plants were identified using textbooks, online catalogues and at the University of Benin Herbarium. Voucher copies of plants in the form of photographs taken were deposited in the Herbarium of the Department of Plant Biology and Biotechnology, University of Benin.

\section{Data analysis}

Fidelity level (FL) quantifies the importance of the species for a given purpose which is defined as the ratio between the number of informants who independently suggested the utilisation of a particular species for treatment of a particular ailment and the total number of informants (Idu et al. 2008).

FL was calculated using the following equation:

$\mathrm{FL}=\mathrm{Np} / \mathrm{N} \times 100$

where

$\mathrm{Np}$ represents the number of informants that reported a use of a plant species to treat a particular ailment.

$\mathrm{N}$ represents the total number of informants.

The importance value (IV) measures the importance of a species to the community. IV was calculated using the following equation: 
$\mathrm{IV}=\mathrm{nis} / \mathrm{n}$

where

nis represents the number of informants who consider a species most important and $\mathrm{n}$ represents the total number of informants.

\section{Results and discussions}

A total of 101 plant species belonging to 46 families were collected. Of these plants, 80 had medicinal uses. The surveyed plants are arranged alphabetically using their botanical name, family names, local name, vernacular name, part used and method of prescription or uses in Table 1. The IV, quotation frequency and FL were also recorded. The plants have been used by the respondents and according to them the plants are effective.
Of the 101 plants, 43 were trees growing in the forests, around farms and in dwelling areas, 29 shrubs, 19 of herbaceous habit and 2 under shrubs (Figure 2). The most represented family was the Fabaceae with 11 species followed by Euphorbiaceae with 6 species and Apocynaceae, Moraceae and Poaceae with 5 species each (Table 2). Economically, the plants are used for various purposes which include birth (during naming ceremonies of newborn babies), traditional marriages, for building and fencing, as edible seeds and fruits and so on (Figure 3).

Home gardens were associated with the majority of the houses visited and most of the plants encountered there have both medicinal and economic uses. One of the most abundant species found in dwelling areas is Calotropis procera which is used to treat cough.

TABLE 1: List of plants with medicinal uses.

\begin{tabular}{|c|c|c|c|c|c|c|c|}
\hline $\begin{array}{l}\text { Serial } \\
\text { number }\end{array}$ & Scientific name & Family & $\begin{array}{l}\text { Vernacular and } \\
\text { common names }\end{array}$ & Parts, uses and modes of preparation & QF & FL $(\%)$ & IV \\
\hline 1. & $\begin{array}{l}\text { Ageratum conyzoides } \mathrm{L} \text {. } \\
\text { (UBHdt/OE/048) }\end{array}$ & Asteraceae & Ebihiso (goat weed) & The leaves are used to treat malaria and ulcer. & 68 & 70 & 0.80 \\
\hline 2. & $\begin{array}{l}\text { Albizia } \\
\text { adianthifolia (Schumach.) } \\
\text { E.FWright. } \\
\text { (UBHdt/OE/003) }\end{array}$ & Fabaceae & $\begin{array}{l}\text { Ugweghele } \\
\text { (flat crown) }\end{array}$ & $\begin{array}{l}\text { The leaves are used to treat cataracts. Squeeze the leaf and } \\
\text { apply the moisture on the eye. }\end{array}$ & 60 & 60 & 0.70 \\
\hline 3. & $\begin{array}{l}\text { Alchornea cordifolia Mill. Arg. } \\
\text { (UBHdt/OE/029) }\end{array}$ & Euphorbiaceae & Ova & $\begin{array}{l}\text { (1) The leaf is used to treat eye-related problems, such as } \\
\text { redness of the eyes. } \\
\text { (2) The leaf is used in combination with other plants to treat } \\
\text { Lassa fever. } \\
\text { (3) Infusion of fresh leaves is used to treat depression of the } \\
\text { head of a newborn. }\end{array}$ & 60 & 60 & 0.70 \\
\hline 4. & $\begin{array}{l}\text { Alstonia boonei De Wild. } \\
\text { (UBHdt/OE/060) }\end{array}$ & Apocynaceae & $\begin{array}{l}\text { Ovughe (cheese } \\
\text { wood, stool wood) }\end{array}$ & It is used to treat fever, diabetes and convulsion. & 70 & 66 & 0.76 \\
\hline 5. & $\begin{array}{l}\text { Ananas comosus (L.) Merr. } \\
\text { (UBHdt/OE/26) }\end{array}$ & Bromeliaceae & $\begin{array}{l}\text { Oghakha } \\
\text { (pineapple) }\end{array}$ & $\begin{array}{l}\text { (1) A decoction of the pineapple is made with other herbs } \\
\text { which are used to treat skin infection and typhoid fever. } \\
\text { (2) The unripe fruit is a vermifuge. }\end{array}$ & 65 & 66 & 0.60 \\
\hline 6. & $\begin{array}{l}\text { Annona senegalensis Pers. } \\
\text { (UBHdt/OE/064) }\end{array}$ & Annonaceae & $\begin{array}{l}\text { Olilibo (custard } \\
\text { apple) }\end{array}$ & The leaves and roots are used to treat infection. & 65 & 60 & 0.60 \\
\hline 7. & $\begin{array}{l}\text { Anthocleista vogelii Afzel. } \\
\text { ExR. Br. } \\
\text { (UBHdt/OE/010) }\end{array}$ & Gentianaceae & Ulemewuwu & $\begin{array}{l}\text { (1) Leaves are used to treat gonorrhoea. } \\
\text { (2) The leaves used to treat barrenness. }\end{array}$ & 66 & 76 & 0.70 \\
\hline 8. & $\begin{array}{l}\text { Antiaris toxicaria Lesch. } \\
\text { (UBHdt/OE/O02) }\end{array}$ & Moraceae & Otokpe (Antiaris) & The stem is used to treat rheumatism. & 60 & 70 & 0.70 \\
\hline 9. & $\begin{array}{l}\text { Azadirachta indica A. Juss. } \\
\text { (UBHdt/OE/092) }\end{array}$ & Meliaceae & Dogoyaro & $\begin{array}{l}\text { It is used to treat malaria. Fresh leaves and bark are boiled } \\
\text { then filtered. A cup is taken daily for three days. }\end{array}$ & 100 & 100 & 1.00 \\
\hline 10. & $\begin{array}{l}\text { Bauhinia reticulate D.C. } \\
\text { (UBHdt/OE/006) }\end{array}$ & Fabaceae & Okhwawiabe & For treating stomach disorders. & 62 & 76 & 0.80 \\
\hline 11. & $\begin{array}{l}\text { Borassus aethiopium Mart. } \\
\text { (UBHdt/OE/014) }\end{array}$ & Arecaceae & $\begin{array}{l}\text { Ogoo (African fan } \\
\text { palm) }\end{array}$ & $\begin{array}{l}\text { It prevents loss of menstruation. A decoction of the seed is } \\
\text { made with other plant combination. }\end{array}$ & 60 & 56 & 0.64 \\
\hline 12. & $\begin{array}{l}\text { Bryophyllum pinnatum (Lam.) } \\
\text { Oken } \\
\text { (UBHdt/OE/096) }\end{array}$ & Crassulaceae & $\begin{array}{l}\text { Okhwokhwo } \\
\text { (resurrection plant, } \\
\text { canterbury bells, } \\
\text { air plant). }\end{array}$ & $\begin{array}{l}\text { (1) It is used to heal the navel of a newborn baby after the } \\
\text { umbilical cord has been cut off. Fresh leaves are squeezed to } \\
\text { extract the liquid. The liquid is applied on the navel once a day. } \\
\text { (2) The leaves used to treat cough. }\end{array}$ & 75 & 70 & 0.80 \\
\hline 13. & $\begin{array}{l}\text { Caesalpinia pulcherrima } \\
\text { (L.) Sw. } \\
\text { (UBHdt/OE/057) }\end{array}$ & Fabaceae & $\begin{array}{l}\text { Otudodo (pride of } \\
\text { Barbados) }\end{array}$ & Used to treat spleen problems. & 60 & 50 & 0.54 \\
\hline 14. & $\begin{array}{l}\text { Calotropis procera (Aiton) } \\
\text { (UBHdt/OE/004) }\end{array}$ & Apocynaceae & Elayeye (calotropis) & A decoction of the leaf is used to cure cough. & 95 & 90 & 0.90 \\
\hline 15. & $\begin{array}{l}\text { Carica papaya L. } \\
\text { (UBHdt/OE/030) }\end{array}$ & Caricaceae & Ayaba (pawpaw) & $\begin{array}{l}\text { The leaves are combined with other leaves to make a } \\
\text { decoction which is used to treat fever. }\end{array}$ & 66 & 70 & 0.64 \\
\hline 16. & $\begin{array}{l}\text { Cascabela thevetia (L.) } \\
\text { Lippold. } \\
\text { (UBHdt/OE/061) }\end{array}$ & Apocynaceae & Bush milk tree & $\begin{array}{l}\text { It prevents skin infection, for example, 'craw craw'. Burn and } \\
\text { mix the leaf with palm oil and rub on the affected regions. }\end{array}$ & 75 & 52 & 0.64 \\
\hline 17. & $\begin{array}{l}\text { Cissus quadrangularis L. } \\
\text { (UBHdt/OE/005) }\end{array}$ & Vitaceae & $\begin{array}{l}\text { Ukhese urauao } \\
\text { (Veldt grape, devil's } \\
\text { backbone) }\end{array}$ & $\begin{array}{l}\text { It is used to treat skin infection. The leaves are boiled and } \\
\text { use to bathe. }\end{array}$ & 72 & 70 & 0.64 \\
\hline 18. & $\begin{array}{l}\text { Citrus sinensis L. } \\
\text { (UBHdt/OE/072) }\end{array}$ & Rutaceae & Omoka (orange) & The leaves and fruits are used to treat skin infection. & 80 & 86 & 0.88 \\
\hline 19. & $\begin{array}{l}\text { Cleome viscosa } \mathrm{L} \text {. } \\
\text { (UBHdt/OE/090) }\end{array}$ & Cleomaceae & Ekuya & $\begin{array}{l}\text { The seeds when eaten help to prevent weak erection } \\
\text { (impotence). }\end{array}$ & 75 & 80 & 0.70 \\
\hline 20. & $\begin{array}{l}\text { Cnestis ferruginea Dc. } \\
\text { (UBHdt/OE/069) }\end{array}$ & Connaraceae & Ebe-khe-ebe & $\begin{array}{l}\text { (1) The moisture from the leaf is used to stop vomiting. } \\
\text { (2) The fruit is eaten three times daily to cure hypertension. }\end{array}$ & 65 & 70 & 0.60 \\
\hline
\end{tabular}


TABLE 1 (Continues...): List of plants with medicinal uses.

\begin{tabular}{|c|c|c|c|c|c|c|c|}
\hline $\begin{array}{l}\text { Serial } \\
\text { number }\end{array}$ & Scientific name & Family & $\begin{array}{l}\text { Vernacular and } \\
\text { common names }\end{array}$ & Parts, uses and modes of preparation & QF & FL $(\%)$ & IV \\
\hline 21. & $\begin{array}{l}\text { Cocos nucifera L. } \\
\text { (UBHdt/OE/059) }\end{array}$ & Areacaceae & Ovibo (coconut) & $\begin{array}{l}\text { (1) A decoction of the root is used to treat dysentery. } \\
\text { (2) The coconut water is used to treat heart failure. The } \\
\text { water is placed in a container and a little salt is added. A cup } \\
\text { is taken three times daily. }\end{array}$ & 95 & 70 & 0.94 \\
\hline 22. & $\begin{array}{l}\text { Cola millenii K. Schum. } \\
\text { (UBHdt/OE/045) }\end{array}$ & Sterculiaceae & Aavua & $\begin{array}{l}\text { Its leaves are used to cure dysentery, stomach pains and for } \\
\text { gynaecological problems. }\end{array}$ & 55 & 54 & 0.76 \\
\hline 23. & $\begin{array}{l}\text { Combretum hispidum Laws. } \\
\text { (UBHdt/OE/011) }\end{array}$ & Combretaceae & Ugbuve & It is used to cure dysentery and piles. & 75 & 60 & 0.60 \\
\hline 24. & $\begin{array}{l}\text { Costos afer Ker Gawl. } \\
\text { (UBHdt/OE/091) }\end{array}$ & Costaceae & Costos & $\begin{array}{l}\text { (1) The stem sap is acidic and burns open wounds. } \\
\text { (2) A decoction of the stem is used to cure cough and } \\
\text { sore throat. }\end{array}$ & 80 & 68 & 0.60 \\
\hline 25. & $\begin{array}{l}\text { Crinum jagus (J. Thomps.) } \\
\text { Dandy } \\
\text { (UBHdt/OE/O70) }\end{array}$ & Amaryllidaceae & Crinum & $\begin{array}{l}\text { (1) It treats snake bite. } \\
\text { (2) The moisture from the leaves aids vomiting. }\end{array}$ & 68 & 60 & 0.60 \\
\hline 26. & $\begin{array}{l}\text { Crotalaria longirostrata Hook } \\
\text { \& Arn. } \\
\text { (UBHdt/OE/068) }\end{array}$ & Fabaceae & Lalo (chipilin) & Its leaves are used to treat stomach disorders. & 65 & 68 & 0.70 \\
\hline 27. & $\begin{array}{l}\text { Cymbopogon citratus L. } \\
\text { (Spreng). } \\
\text { (UBHdt/OE/O01) }\end{array}$ & Poaceae & Lemon grass & $\begin{array}{l}\text { (1) Leaves are used to treat rheumatism. } \\
\text { (2) A decoction of the leaves in combination with other } \\
\text { leaves is used to treat fever and prevent cold. }\end{array}$ & 95 & 96 & 0.60 \\
\hline 28. & $\begin{array}{l}\text { Dacryodes edulis H.J Lam. } \\
\text { (UBHdt/OE/O20) }\end{array}$ & Burseraceae & Oomen (pear tree) & It is used to treat constipation. Boil the leaves and drink. & 68 & 60 & 0.70 \\
\hline 29. & $\begin{array}{l}\text { Datura metel L. } \\
\text { (UBHdt/OE/O39) }\end{array}$ & Solanaceae & $\begin{array}{l}\text { Igbalodo (devil's } \\
\text { trumpet, metel) }\end{array}$ & A decoction of the leaves is used to treat chronic boils. & 60 & 56 & 56 \\
\hline 30. & $\begin{array}{l}\text { Dialium indum L. } \\
\text { (UBHdt/OE/049) }\end{array}$ & Fabaceae & $\begin{array}{l}\text { Uge (tamarind } \\
\text { plum) }\end{array}$ & $\begin{array}{l}\text { (1) The leaves are used as a tonic. } \\
\text { (2) The seeds are used to treat stomach disorders. }\end{array}$ & 85 & 70 & 0.70 \\
\hline 31. & $\begin{array}{l}\text { Dioscorea dumetorum (Knuth) } \\
\text { Pax. } \\
\text { (UBHdt/OE/015) }\end{array}$ & Dioscoreaceae & Uhulu (yam) & $\begin{array}{l}\text { Its root tuber is used to wash the wound two times daily to } \\
\text { treat unhealing wounds. }\end{array}$ & 95 & 70 & 1.00 \\
\hline 32. & $\begin{array}{l}\text { Dracaena aletriformis (Haw.) } \\
\text { Bos } \\
\text { (UBHdt/OE/047) }\end{array}$ & Asparagaceae & $\begin{array}{l}\text { Owawa (large- } \\
\text { leaved dragon tree) }\end{array}$ & $\begin{array}{l}\text { (1) A decoction of the leaves is used to treat children's } \\
\text { cough. } \\
\text { (2) The leaves are chewed to treat sore throat. }\end{array}$ & 65 & 76 & 0.76 \\
\hline 33. & $\begin{array}{l}\text { Dracaena mildbraedii K. Krause } \\
\text { (UBHdt/OE/093) }\end{array}$ & Asparagaceae & Khisewu & $\begin{array}{l}\text { (1) The leaves are used to cure gonorrhoea and treat } \\
\text { stomach problem. }\end{array}$ & 65 & 60 & 60 \\
\hline 34. & $\begin{array}{l}\text { Elaeis guineensis Jacq. } \\
\text { (UBHdt/OE/065) }\end{array}$ & Arecaceae & Otaghie (palm tree) & $\begin{array}{l}\text { (1) Pound the leaves in a mortar with palm wine. The juice is } \\
\text { squeezed and applied to the body to treat convulsion. } \\
\text { (2) Pound the leaves and mix with palm wine. Take a cup } \\
\text { thrice daily to treat dysentery. }\end{array}$ & 100 & 66 & 0.8 \\
\hline 35. & $\begin{array}{l}\text { Eucalyptus radiate Sieber ex } \\
\text { DC. } \\
\text { (UBHdt/OE/016) }\end{array}$ & Myrataceae & Otiba (fever tree) & $\begin{array}{l}\text { (1) Leaves are used to treat urinary tract infection. } \\
\text { (2) Used to treat asthma. } \\
\text { (3) Used to treat typhoid. Fill a pot with fresh leaves and } \\
\text { bring to boil. Allow to cool for } 12 \mathrm{~h} \text {. Take a glassful three } \\
\text { times daily. }\end{array}$ & 100 & 60 & 0.60 \\
\hline 36. & $\begin{array}{l}\text { Ficus exasperate Vahl. } \\
\text { (UBHdt/OE/058) }\end{array}$ & Moraceae & Sandpaper tree & $\begin{array}{l}\text { (1) A decoction of the leaf is used to treat enlargement of } \\
\text { the liver. } \\
\text { (2) It is used to treat piles. Fresh leaves are squeezed in } \\
\text { water and then filtered. A cup is taken three times daily for } \\
\text { five days. }\end{array}$ & 90 & 65 & 0.70 \\
\hline 37. & $\begin{array}{l}\text { Ficus sur Forssk } \\
\text { (UBHdt/OE/025) }\end{array}$ & Moraceae & Ovua (cape fig) & Seeds and leaves are used to treat eye problems. & 75 & 70 & 0.70 \\
\hline 38. & $\begin{array}{l}\text { Glyphaea brevis (Spreng) } \\
\text { (UBHdt/OE/017) }\end{array}$ & Tiliaceae & Uwakhi (goat cain) & $\begin{array}{l}\text { (1) The leaf juice is used to treat cuts and wounds. } \\
\text { (2) Enemas from the leaves are given to pregnant women to } \\
\text { ensure quick and easy labour. }\end{array}$ & 86 & 74 & 0.76 \\
\hline 39. & $\begin{array}{l}\text { Gossypium herbaceum L. } \\
\text { (UBHdt/OE/065) }\end{array}$ & Malvaceae & Olulu (cotton) & $\begin{array}{l}\text { It is used to treat stomach pain and rheumatism. } \\
\text { A decoction of the leaf is made and drank. }\end{array}$ & 65 & 76 & 0.54 \\
\hline 40. & $\begin{array}{l}\text { Harungana madagascariensis } \\
\text { Lam. Ex Poiret } \\
\text { (UBHdt/OE/018) }\end{array}$ & Hypericaceae & Orarade & Leaves are used to prevent menstruation loss and fever. & 68 & 54 & 0.76 \\
\hline 41. & $\begin{array}{l}\text { Helianthus annus L. } \\
\text { (UBHdt/OE/019) }\end{array}$ & Asteraceae & Ebeja (sunflower) & $\begin{array}{l}\text { (1) It is used to treat stomach disorder. } \\
\text { (2) The leaves are used to treat convulsion. }\end{array}$ & 65 & 60 & 0.64 \\
\hline 42. & $\begin{array}{l}\text { Hevea brasilensis Mull. Arg. } \\
\text { (UBHdt/OE/050) }\end{array}$ & Asteraceae & $\begin{array}{l}\text { Otaaba (para } \\
\text { rubber tree) }\end{array}$ & The seeds are used to soften the hard spot of baby's head. & & & \\
\hline 43. & $\begin{array}{l}\text { Hyptis suaveolens (L.) Poit } \\
\text { (UBHdt/OE/027) }\end{array}$ & Liamiaceae & Abesu & Leaves are used to cure typhoid fever. & 80 & 76 & 0.76 \\
\hline 44. & $\begin{array}{l}\text { Icacina trichantha Oliv. } \\
\text { (UBHdt/OE/02) }\end{array}$ & Icacinaceae & Urokhoma & $\begin{array}{l}\text { (1) Squeeze the moisture from the leaf and drink. It induces } \\
\text { vomiting in the case of food poisoning. } \\
\text { (2) Grind the fresh root and use to make soup. Drink the } \\
\text { soup daily to reduce menstrual pain. }\end{array}$ & 70 & 70 & 0.60 \\
\hline 45. & $\begin{array}{l}\text { Jathropa crucas L. } \\
\text { (UBHdt/OE/054) }\end{array}$ & Euphorbiaceae & $\begin{array}{l}\text { Ugaubau (Barbados } \\
\text { nut, physic nut) }\end{array}$ & $\begin{array}{l}\text { (1) It is used to cure gonorrhoea. } \\
\text { (2) The latex is applied to fresh wounds to stop bleeding. } \\
\text { (3) It is used to cure fibroid. Boil the leaves and root with } \\
\text { onion and garlic. Take half glass three times daily for } \\
\text { three months. }\end{array}$ & 86 & 78 & 0.70 \\
\hline 46. & $\begin{array}{l}\text { Khaya ivorensis A. Chev. } \\
\text { (UBHdt/OE/O24) }\end{array}$ & Meliaceae & $\begin{array}{l}\text { Otaokpe } \\
\text { (mahogany) }\end{array}$ & $\begin{array}{l}\text { (1) The leaves or bark can be used to treat diabetes and } \\
\text { chest pain. } \\
\text { (2) It is used to treat irregular menstruation. Cut the bark } \\
\text { into pieces and soak for } 24 \mathrm{~h} \text {. Drink a glassful twice daily. }\end{array}$ & 80 & 56 & 0.70 \\
\hline 47. & $\begin{array}{l}\text { Kigelia Africana (Lam.) Benth } \\
\text { (UBHdt/OE/088) }\end{array}$ & Bignoniaceae & $\begin{array}{l}\text { Osuoyan (kigelia, } \\
\text { sausage tree) }\end{array}$ & $\begin{array}{l}\text { Its fruits are used to prevent rheumatism. Cut and boil in } \\
\text { water and use to bathe. }\end{array}$ & 70 & 66 & 0.76 \\
\hline
\end{tabular}


TABLE 1 (Continues...): List of plants with medicinal uses.

\begin{tabular}{|c|c|c|c|c|c|c|c|}
\hline $\begin{array}{l}\text { Serial } \\
\text { number }\end{array}$ & Scientific name & Family & $\begin{array}{l}\text { Vernacular and } \\
\text { common names }\end{array}$ & Parts, uses and modes of preparation & QF & FL (\%) & IV \\
\hline 48. & $\begin{array}{l}\text { Laggera aurita Linn. F } \\
\text { (UBHdt/OE/066) }\end{array}$ & Asteraceae & Itabasa imhin & It prevents asthma. & 55 & 80 & 0.80 \\
\hline 49. & $\begin{array}{l}\text { Laportea ovalifolia (Schumach. } \\
\text { \& Thonn) } \\
\text { (UBHdt/OE/023) }\end{array}$ & Urticaceae & Stinging nesto & $\begin{array}{l}\text { (1) It cures hypertension. } \\
\text { (2) It purifies the blood. The leaves are used to make a } \\
\text { decoction. Or the moisture from the leaves is squeezed out } \\
\text { and milk is added and the mixture is taken orally. }\end{array}$ & 70 & 68 & 0.54 \\
\hline 50. & $\begin{array}{l}\text { Lantana camara L. } \\
\text { (UBHdt/OE/031) }\end{array}$ & Verbenaceae & $\begin{array}{l}\text { Okhuekhue } \\
\text { (tickberry, white } \\
\text { sage) }\end{array}$ & $\begin{array}{l}\text { (1) It is used to treat hypertension. } \\
\text { (2) It is used to treat convulsion. }\end{array}$ & 66 & 76 & 0.76 \\
\hline 51. & $\begin{array}{l}\text { Loranthus bangwensis L. } \\
\text { (UBHdt/OE/044) }\end{array}$ & Loranthaceae & $\begin{array}{l}\text { Usi (African } \\
\text { mistletoe) }\end{array}$ & $\begin{array}{l}\text { (1) It is used to treat epilepsy. } \\
\text { (2) It is used to treat liver problems. Soak } 4-7 \text { leaves in a cup } \\
\text { of water overnight, add a cup of hot water and drink every } \\
\text { morning and night. }\end{array}$ & 90 & 80 & 0.80 \\
\hline 52. & $\begin{array}{l}\text { Mangifera indica L. } \\
\text { (UBHdt/OE/053) }\end{array}$ & Anacardiaceae & Umango (mango) & $\begin{array}{l}\text { (1) The stem bark is used to make a decoction that is used to } \\
\text { treat anaemia. } \\
\text { (2) Fresh leaves are boiled and a glass of the mixture is taken } \\
\text { three times daily to prevent diabetes. }\end{array}$ & 85 & 84 & 0.84 \\
\hline 53. & $\begin{array}{l}\text { Milicia excels (Welw.) C.C. Berg } \\
\text { (UBHdt/OE/062) }\end{array}$ & Moraceae & Uloko (iroko) & $\begin{array}{l}\text { (1) The leaves are used to treat stomach pain. } \\
\text { (2) It is used as a treatment for rheumatism. A decoction of } \\
\text { the leaves and other plant part is used. }\end{array}$ & 80 & 84 & 0.84 \\
\hline 54. & $\begin{array}{l}\text { Morinda lucida Benth. } \\
\text { (UBHdt/OE/032) }\end{array}$ & Rubiaceae & Alomo & Leaves are used to treat diabetes, fever and jaundice. & 60 & 60 & 64 \\
\hline 55. & $\begin{array}{l}\text { Mormordica charantia L. } \\
\text { (UBHdt/OE/043) }\end{array}$ & Curcurbitaceae & $\begin{array}{l}\text { Elohn (African } \\
\text { cucumber) }\end{array}$ & $\begin{array}{l}\text { (1) Leaves are used to treat piles. } \\
\text { (2) It is used to treat diabetes. } \\
\text { (3) It is used to treat stomach pain and poor menstruation. }\end{array}$ & 80 & 84 & 0.84 \\
\hline 56. & $\begin{array}{l}\text { Mucuna poggei Taub. } \\
\text { (UBHdt/OE/071) }\end{array}$ & Fabaceae & $\begin{array}{l}\text { Ughelekpe } \\
\text { (mucuna) }\end{array}$ & The root is used to treat mental problems. & 70 & 70 & 0.70 \\
\hline 57. & $\begin{array}{l}\text { Musa paradisiaca L. } \\
\text { (UBHdt/OE/033) }\end{array}$ & Musaceae & Ogede (plantain) & $\begin{array}{l}\text { (1) The root is used to treat goitre. Crush the root and } \\
\text { squeeze out the moisture. Mix with an equal quantity of } \\
\text { honey. } \\
\text { Three tablespoons are taken three times daily. } \\
\text { (2) To treat kidney complications. It is prepared as above. } \\
\text { Four tablespoons are taken three times daily. } \\
\text { (3) It is used to treat anaemia. A decoction of the root is } \\
\text { prepared and drunk. } \\
\text { (4) A decoction of the stem is taken three times daily to treat } \\
\text { cholera. }\end{array}$ & 85 & 90 & 0.90 \\
\hline 58. & $\begin{array}{l}\text { Nicotiana tabacum L. } \\
\text { (UBHdt/OE/042) }\end{array}$ & Solanaceae & Ebetaba (tobacco) & $\begin{array}{l}\text { (1) It is used to treat asthma. } \\
\text { (2) The leaves are also used as an anticonvulsant. }\end{array}$ & 62 & 72 & 0.80 \\
\hline 59. & $\begin{array}{l}\text { Parkia biglobosa (Jacq.) R.Br } \\
\text { (UBHdt/OE/094) }\end{array}$ & Fabaceae & $\begin{array}{l}\text { Otowa (African } \\
\text { locust bean) }\end{array}$ & The leaves are used to treat headache. & 65 & 56 & 0.76 \\
\hline 60. & $\begin{array}{l}\text { Paullinia pinnata L. } \\
\text { (UBHdt/OE/075) }\end{array}$ & Sapindaceae & Ughiegho & $\begin{array}{l}\text { A decoction of the root is drunk for enlargement of the } \\
\text { penis. }\end{array}$ & 80 & 60 & 0.60 \\
\hline 61. & $\begin{array}{l}\text { Pedilanthus tithymaloides L. } \\
\text { (UBHdt/OE/037) }\end{array}$ & Euphorbiaceae & & $\begin{array}{l}\text { A decoction of the leaves is used to bathe in treatment of } \\
\text { skin infection. }\end{array}$ & 70 & 60 & 0.60 \\
\hline 62. & $\begin{array}{l}\text { Pennisetum purpureum } \\
\text { Schumach } \\
\text { (UBHdt/OE/040) }\end{array}$ & Poaceae & $\begin{array}{l}\text { Ohien (elephant } \\
\text { grass) }\end{array}$ & $\begin{array}{l}\text { It is used to cure chest pain. The root is combined with other } \\
\text { plant parts to make a decoction. }\end{array}$ & 80 & 80 & 0.54 \\
\hline 63. & $\begin{array}{l}\text { Pergularia daemia (Forssk.) } \\
\text { Chiov. } \\
\text { (UBHdt/OE/087) }\end{array}$ & Apocynaceae & Ulele & $\begin{array}{l}\text { (1) The leaves are used to treat stomach pains and skin } \\
\text { disorders, for example 'craw craw'. }\end{array}$ & 70 & 70 & 0.64 \\
\hline 64. & $\begin{array}{l}\text { Phyllantus niruri L. } \\
\text { (UBHdt/OE/076) }\end{array}$ & Phyllantaceae & $\begin{array}{l}\text { Ebisowa (gale of the } \\
\text { wind) }\end{array}$ & $\begin{array}{l}\text { The leaves are used in combination with other herbs to treat } \\
\text { stomach pain and appendicitis. }\end{array}$ & 66 & 68 & 0.70 \\
\hline 65. & $\begin{array}{l}\text { Psidium guajava L. } \\
\text { (UBHdt/OE/034) }\end{array}$ & Myrtaceae & Egova (guava) & $\begin{array}{l}\text { Infusion of the leaves: a cup is taken thrice daily to treat } \\
\text { hypertension. }\end{array}$ & 60 & 80 & 80 \\
\hline 66. & $\begin{array}{l}\text { Rauwolfia vomitoria Afzel. } \\
\text { (UBHdt/OE/063) }\end{array}$ & Apocynaceae & Uhughi & $\begin{array}{l}\text { (1) It is used to treat impotence. Boil fresh root in water and } \\
\text { drink half glass every night. } \\
\text { (2) The leaves are used in the treatment of smallpox. Boil the } \\
\text { leaves and use the moisture to bathe. }\end{array}$ & 85 & 78 & 0.80 \\
\hline 67. & $\begin{array}{l}\text { Ricinus communis L. } \\
\text { (UBHdt/OE/097) }\end{array}$ & Euphorbiaceae & Castor plant & The leaves are used to treat skin diseases. & 60 & 64 & 0.64 \\
\hline 68. & $\begin{array}{l}\text { Senna occidentalis (L.) Link. } \\
\text { (UBHdt/OE/082) }\end{array}$ & Fabaceae & $\begin{array}{l}\text { Eraghatosaime } \\
\text { (coffee senna) }\end{array}$ & $\begin{array}{l}\text { Leaves are used in the treatment of stomach pain and } \\
\text { chronic dysentery. }\end{array}$ & 60 & 60 & 0.60 \\
\hline 69. & $\begin{array}{l}\text { Senna siamea Lam. } \\
\text { (UBHdt/OE/098) }\end{array}$ & Fabaceae & $\begin{array}{l}\text { Oti cassia (cassia } \\
\text { tree) }\end{array}$ & Its leaves are used to treat malaria and typhoid. & 65 & 70 & 0.76 \\
\hline 70. & $\begin{array}{l}\text { Sida acuta Burm. F } \\
\text { (UBHdt/OE/086) }\end{array}$ & Malvaceae & $\begin{array}{l}\text { Orarighun (wire } \\
\text { weed) }\end{array}$ & $\begin{array}{l}\text { (1) The leaves are used to treat malaria and arthritis. } \\
\text { A decoction of the fresh leaf is made. Take half a glass three } \\
\text { times daily for arthritis and take a glassful three times daily } \\
\text { for malaria. } \\
\text { (2) The crushed leaves are applied to fresh cuts to stop } \\
\text { bleeding. }\end{array}$ & 90 & 70 & 0.7 \\
\hline 71. & $\begin{array}{l}\text { Solanum torvum Swartz. } \\
\text { (UBHdt/OE/035) }\end{array}$ & Solanaceae & $\begin{array}{l}\text { Igbalode (devil's fig, } \\
\text { wild fig) }\end{array}$ & $\begin{array}{l}\text { (1) The leaves are used to treat snake and scorpion bites. } \\
\text { (2) It is used to treat gonorrhoea. }\end{array}$ & 77 & 60 & 0.60 \\
\hline 72. & $\begin{array}{l}\text { Spondias mombin L. } \\
\text { (UBHdt/OE/095) }\end{array}$ & Anacardiaceae & Ukhian (hog plum) & $\begin{array}{l}\text { (1) The leaves are used to treat dysentery. } \\
\text { (2) A decoction of the leaves is used to wash the face thrice } \\
\text { daily to treat short-sightedness. }\end{array}$ & 60 & 76 & 0.76 \\
\hline 73. & $\begin{array}{l}\text { Sterculia tragacantha Lindl. } \\
\text { (UBHdt/OE/080) }\end{array}$ & Sterculiaceae & Aikpa & Leaves are used to treat cough and dysentery. & 60 & 80 & 0.8 \\
\hline 74. & $\begin{array}{l}\text { Telfairia occidentalis Hook. F } \\
\text { (UBHdt/OE/085) }\end{array}$ & Curcurbitaceae & Umeke (pumpkin) & $\begin{array}{l}\text { (1) The leaves are used as a blood tonic. Wash the leaves and } \\
\text { drink the moisture. }\end{array}$ & 75 & 80 & 80 \\
\hline
\end{tabular}


TABLE 1 (Continues...): List of plants with medicinal uses.

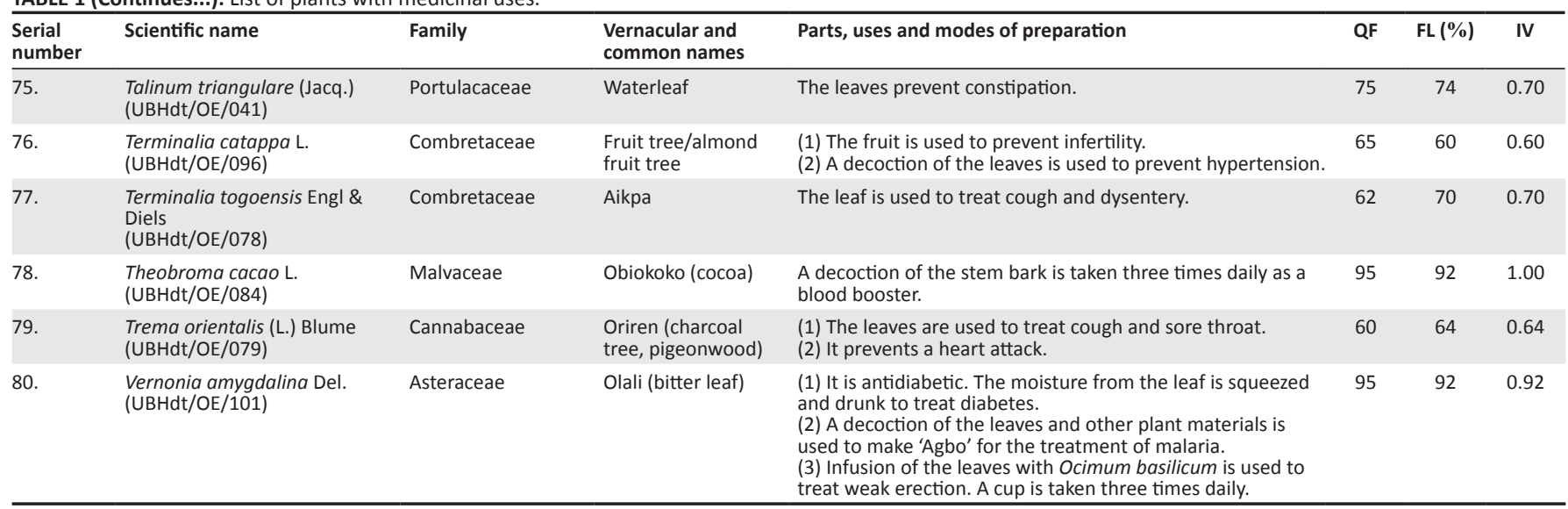

$\mathrm{QF}$, quotation frequency; FL, fidelity level; IV, importance value.

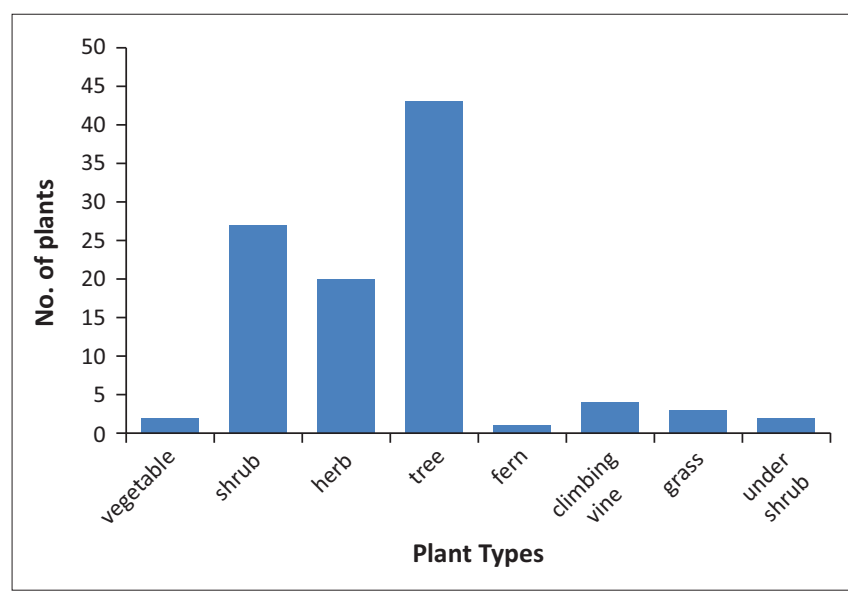

FIGURE 2: Distribution of Plant types in Otuo, Owan East Local Government Area, Nigeria.

Plants with medicinal uses summed up to 80 (Table 1) and are used to treat a host of ailments. Medicinal plants used to treat stomach pain and cough were the most abundant followed by those used in treating rheumatism, skin infection, fever, gonorrhoea and diabetes (Figure 4).

The majority of the plants had high FLs and IVs. Azadirachta indica and Cymbopogon citratus had the highest FLs of 100 and 96 and are both used in the treatment of malaria. A plant can have more than one medicinal uses as in the case of Eucalyptus officinalis, which is used in the treatment of typhoid, urinary tract infection and asthma, and the herbalists in most cases use different plants of their choice to treat a specific ailment; for example, stomach pain can be treated using Crotalaria longirostrata, Dialium indum, Pergularia daemia or Phyllanthus niruri. Most of the plant remedies were prepared from a single plant source, while a few others have to be in combination with other plants.

The plants that have ethnobotanical uses were 58 (Table 2) and the majority of them are used for food. The majority of the plants studied had both economic and medicinal properties like Ficus exasperata which is used as a washing agent for pots and also used in the treatment of piles. Also, Psidium guajava is eaten as a fruit and used medicinally in the treatment of hypertension.
Plants with magical and spiritual use such as Gomphrena celosioides were usually accompanied by some spells and incantations known by the herbalists or witchdoctors alone.

In the Otuo tribe, traditional medicine is still widely practised, and the herbalists believe that plants provide better means of treating various ailments than orthodox medicines. It has been recorded that traditional medicine is the source of primary healthcare to $80 \%$ of the world's population (Hoffman \& Gallaher 2007). Traditional healers have claimed success in the treatment of various ailments like gonorrhoea, diabetes and other diseases. Ariba et al. (2007) reported that $42.3 \%$ of Nigerian clinicians agreed that many patients prefer native medications to modern drugs. This also supports the use of herbs for treatment of various ailments by the Otuo people of Edo State.

In the survey previously performed on the ethnomedicinal plants found in the Otuo clan, 51 species of plants were recorded (Idu et al. 2006), and, of these, 22 were repeated in this study. A total of 79 new plants were recorded in this survey. In total, this study has shown 80 plants with medicinal properties. The ethnomedicinal uses of the plants mentioned in the previous survey are in accordance with this survey. This shows the effectiveness and general use of these plants by the Otuo people.

There is an urgent need to preserve our biodiversity as there is a rapid increase in the extinction of plant species. Conservation should be practised to protect plant species from overexploitation, destruction and extinction. In addition, most of these plants are not being documented (Idu et al. 2006); efforts should be made to record and document the knowledge of traditional medicines by the various herbalists before such knowledge goes extinct. This is important to boost the economic improvements which the sales of these remedies have brought to poor homes in the study area.

A major challenge is the secrecy of the knowledge of the plants by the various herbalists as most of them 
TABLE 2: List of plants with economic uses

\begin{tabular}{|c|c|c|c|c|c|c|}
\hline$S / N$ & Scientific name & Family & $\begin{array}{l}\text { Vernacular and common } \\
\text { names }\end{array}$ & Description & QF & IV \\
\hline 1. & $\begin{array}{l}\text { Abelmoschus esculentus (L.) } \\
\text { Moench } \\
\text { (UBHdt/OE/021) }\end{array}$ & Malvaceae & Unno (okra, ladies' finger) & $\begin{array}{l}\text { (1) The fruit is used in soup making. } \\
\text { (2) It is eaten to clear the voice. }\end{array}$ & 66 & 0.60 \\
\hline 2. & $\begin{array}{l}\text { Agave americana } \mathrm{L} . \\
\text { (UBHdt/OE/012) }\end{array}$ & Asparagaceae & Century plant & It is ornamental. & 25 & 0.40 \\
\hline 3. & $\begin{array}{l}\text { Ageratum conyzoides L. } \\
\text { (UBHdt/OE/048) }\end{array}$ & Asteraceae & Ebihiso (goat weed) & The leaves give energy. & 68 & 0.80 \\
\hline 4. & $\begin{array}{l}\text { Anacardium occidentale L. } \\
\text { (UBHdt/OE/O07) }\end{array}$ & Anacardiaceae & Icashew (cashew) & The fruit is eaten and provides nutrients. & 60 & 0.84 \\
\hline 5. & $\begin{array}{l}\text { Annona muricata L. } \\
\text { (UBHdt/OE/099) }\end{array}$ & Annonaceae & Oghiasoibo (sour sop) & The fruit is edible. & 65 & 0.60 \\
\hline 6. & $\begin{array}{l}\text { Ananas comosus (L.) Merr. } \\
\text { (UBHdt/OE/O26) }\end{array}$ & Bromeliaceae & Oghakha (pineapple) & $\begin{array}{l}\text { The fruit is edible and serves as a source } \\
\text { of nutrients. }\end{array}$ & 65 & 0.60 \\
\hline 7. & $\begin{array}{l}\text { Anogeissus leiocarpa (Dc) } \\
\text { Guill.and Perr. } \\
\text { (UBHdt/OE/67) }\end{array}$ & Combretaceae & Otauwi & $\begin{array}{l}\text { (1) The roots are used as chewing stick. } \\
\text { (2) The leaf ashes are used for dyeing. }\end{array}$ & 65 & 0.64 \\
\hline 8. & $\begin{array}{l}\text { Anthocleista vogelii Afzel. Ex R. } \\
\mathrm{Br}(\mathrm{UBHdt} / \mathrm{OE} / 010)\end{array}$ & Gentianaceae & Ulemewuwu & The leaves are used as a laxative. & 66 & 0.70 \\
\hline 9. & $\begin{array}{l}\text { Antiaris toxicaria Lesch. } \\
\text { (UBHdt/OE/002) }\end{array}$ & Moraceae & Otokpe (Antiaris) & $\begin{array}{l}\text { The stem is used in furniture and } \\
\text { roofing. }\end{array}$ & 60 & 0.70 \\
\hline 10. & $\begin{array}{l}\text { Arachis hypogea L. } \\
\text { (UBHdt/OE/013) }\end{array}$ & Fabaceae & Isaigue (groundnut) & $\begin{array}{l}\text { (1) The seeds are a source of cooking oil. } \\
\text { (2) Seeds are also eaten as a source of } \\
\text { protein. }\end{array}$ & 66 & 0.70 \\
\hline 11. & $\begin{array}{l}\text { Athyrium asplenioides (L.) } \\
\text { Roth. } \\
\text { (UBHdt/OE/052) }\end{array}$ & Meliaceae & Fern & It is used for spiritual consultation. & 60 & 0.76 \\
\hline 12. & $\begin{array}{l}\text { Azadirachta indica Juss. } \\
\text { (UBHdt/OE/092) }\end{array}$ & Meliaceae & Dogoyaro & The stem is used as firewood. & 100 & 1.00 \\
\hline 13. & $\begin{array}{l}\text { Bambusa vulgaris Schrad Ex } \\
\text { J.C. Wendel. } \\
\text { (UBHdt/OE/074) }\end{array}$ & Poaceae & Bamboo & The stem is used in building. & 55 & 0.54 \\
\hline 14. & $\begin{array}{l}\text { Bauhinia reticulata } \\
\text { D.C. (UBHdt/OE/O06) }\end{array}$ & Fabaceae & Okhwawiabe & Leaves and fruits act as appetizers. & 62 & 0.80 \\
\hline 15. & $\begin{array}{l}\text { Borassus aethiopum Mart. } \\
\text { (UBHdt/OE/014) }\end{array}$ & Arecaceae & Ogoo (African fan palm) & $\begin{array}{l}\text { (1) It produces palm wine. } \\
\text { (2) The seeds are used to harden the } \\
\text { soft spot of a new born baby's head. }\end{array}$ & 60 & 0.64 \\
\hline 16. & $\begin{array}{l}\text { Calotropis procera (Aiton) } \\
\text { Dryand } \\
\text { (UBHdt/OE/004) }\end{array}$ & Apocynaceae & Elayeye (calotropis) & Its leaves are ornamental. & 95 & 0.90 \\
\hline 17. & $\begin{array}{l}\text { Canavalia gladiata (Jacq.) Dc } \\
\text { (UBHdt/OE/056) }\end{array}$ & Fabaceae & Ugbewe (sword bean tree) & $\begin{array}{l}\text { (1) Leaves serve as a source of } \\
\text { vegetable. } \\
\text { (2) The fruits are eaten. }\end{array}$ & 55 & 0.60 \\
\hline 18. & $\begin{array}{l}\text { Carica papaya L. } \\
\text { (UBHdt/OE/O30) }\end{array}$ & Caricaceae & Ayaba (pawpaw) & Its fruits and leaves are eaten as food. & 66 & 0.64 \\
\hline 19. & $\begin{array}{l}\text { Cascabela thevetia (L.) Lippold } \\
\text { (UBHdt/OE/061) }\end{array}$ & Apocynaceae & Bush milktree & It is an ornamental tree. & 75 & 0.64 \\
\hline 20. & $\begin{array}{l}\text { Citrus sinensis } \mathrm{L} \text {. } \\
\text { (UBHdt/OE/072) }\end{array}$ & Rutaceae & Omoka (orange) & The fruits are edible. & 80 & 0.88 \\
\hline 21. & $\begin{array}{l}\text { Cleome viscosa L. } \\
\text { (UBHdt/OE/O90) }\end{array}$ & Cleomaceae & Ekuya & The seeds can be eaten. & 75 & 0.70 \\
\hline 22. & $\begin{array}{l}\text { Cocos nucifera L. } \\
\text { (UBHdt/OE/059) }\end{array}$ & Areacaceae & Ovibo (coconut) & The fruit is eaten. & 95 & 0.94 \\
\hline 23. & $\begin{array}{l}\text { Coffea arabica } \mathrm{L} \text {. } \\
\text { (UBHdt/OE/O08) }\end{array}$ & Rubiaceae & Otasi-Cofi (coffee tree) & It relaxes the brain. & 58 & 0.70 \\
\hline 24. & $\begin{array}{l}\text { Cymbopogon citratus L. } \\
\text { (Spreng) } \\
\text { (UBHdt/OE/001) }\end{array}$ & Poaceae & Lemon grass & Leaves are ornamental. & 95 & 0.60 \\
\hline 25. & $\begin{array}{l}\text { Dacryodes edulis H.J. Lam } \\
\text { (UBHdt/OE/020) }\end{array}$ & Burseraceae & Oomen (pear tree) & The fruits are eaten. & 68 & 0.70 \\
\hline 26. & $\begin{array}{l}\text { Dialium indum L. } \\
\text { (UBHdt/OE/49) }\end{array}$ & Fabaceae & Uge (tamarind plum) & $\begin{array}{l}\text { (1) The leaves are used as a tonic. } \\
\text { (2) Seeds give energy. }\end{array}$ & 85 & 0.70 \\
\hline 27. & $\begin{array}{l}\text { Dioscorea dumetorum } \\
\text { (Knuth) Pax. (UBHdt/OE/015) }\end{array}$ & Dioscoreaceae & Uhulu (yam) & Root tubers are used as food. & 95 & 1.00 \\
\hline 28. & $\begin{array}{l}\text { Elaeis guineensis Jacq. } \\
\text { (UBHdt/OE/065) }\end{array}$ & Arecaceae & Otaghie (palm tree) & $\begin{array}{l}\text { (1) The palm fronds are used in } \\
\text { sweeping, making shades and during } \\
\text { religious and cultural festivals. } \\
\text { (2) The palm nut is a source of oil. } \\
\text { (3) The palm kernel serves as a source of } \\
\text { food. }\end{array}$ & 100 & 0.8 \\
\hline 29. & $\begin{array}{l}\text { Ficus exasperata Vahl. } \\
\text { (UBHdt/OE/058) }\end{array}$ & Moraceae & Sandpaper tree & The leaves are used for washing of pots. & 90 & 0.70 \\
\hline 30. & $\begin{array}{l}\text { Ficus sur Forssk } \\
\text { (UBHdt/OE/025) }\end{array}$ & Moraceae & Ovua (Cape fig) & $\begin{array}{l}\text { The oil from the seed is used to prevent } \\
\text { whiteness of children's tongues. }\end{array}$ & 75 & 0.70 \\
\hline 31. & $\begin{array}{l}\text { Gomphrena celosoides Mart. } \\
\text { (UBHdt/OE/089) }\end{array}$ & Amaranthaceae & Sheshefu & It is used for spiritual washing. & 60 & 0.80 \\
\hline
\end{tabular}


TABLE 2 (Continues...): List of plants with economic uses.

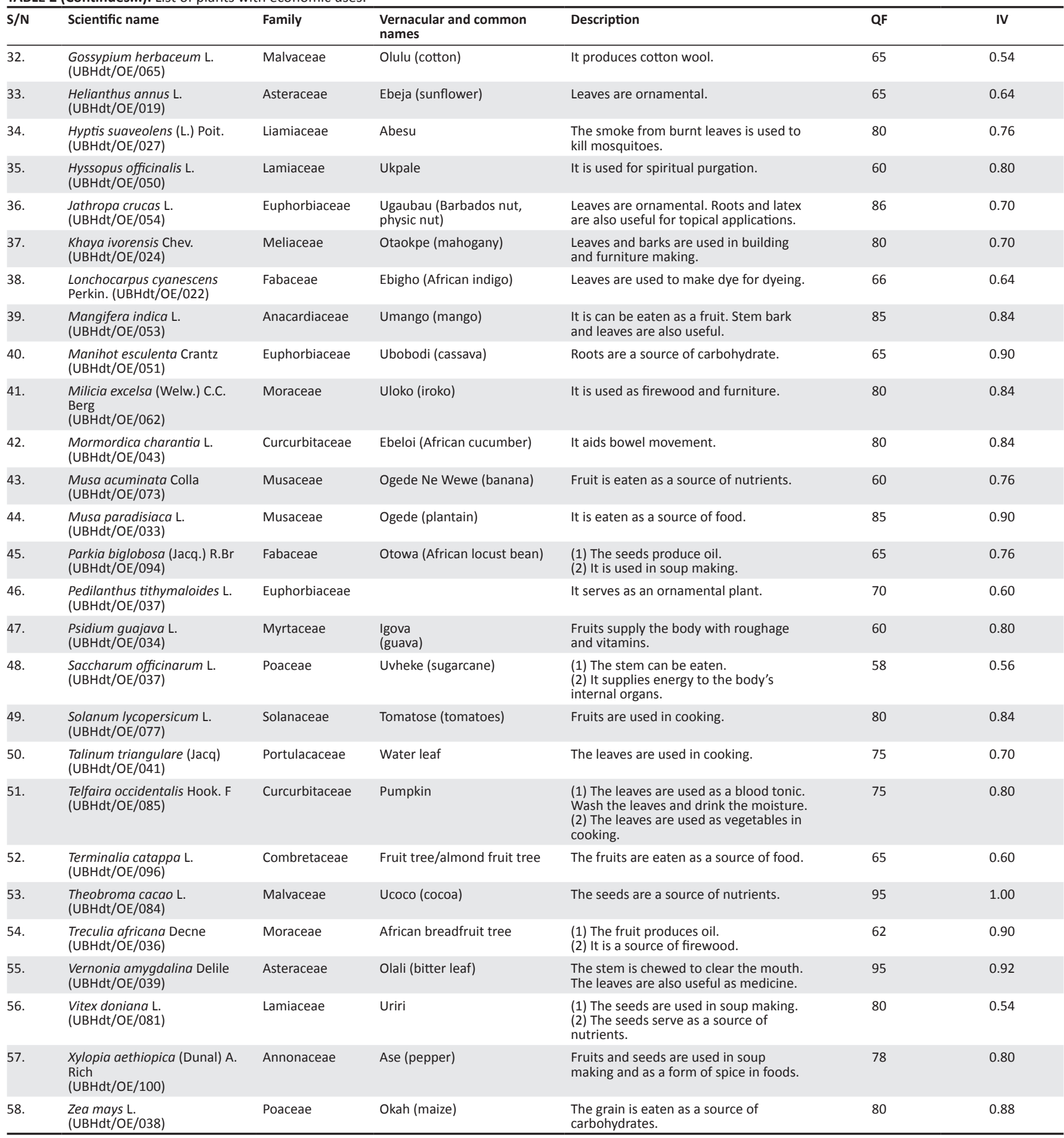

$\mathrm{QF}$, quotation frequency; IV, importance value.

keep valuable information to themselves believing one has come to take their knowledge from them and thus die with the information and sometimes fail to pass it on to the next generation to enhance its continuity. This has hindered the development and improvement of traditional medicine in Nigeria. These herbalists have to be enlightened on the importance of making their knowledge known to others and encouraged to give useful information on medicinal plants around their area (Ogbor 1989).

Nigeria has a vast heritage of medicinal and traditional knowledge. The use of traditional knowledge will continue to play a vital role in the healthcare delivery system in Nigeria as long as modern health care facilities continue to be unavailable to the populace especially in the rural areas. 


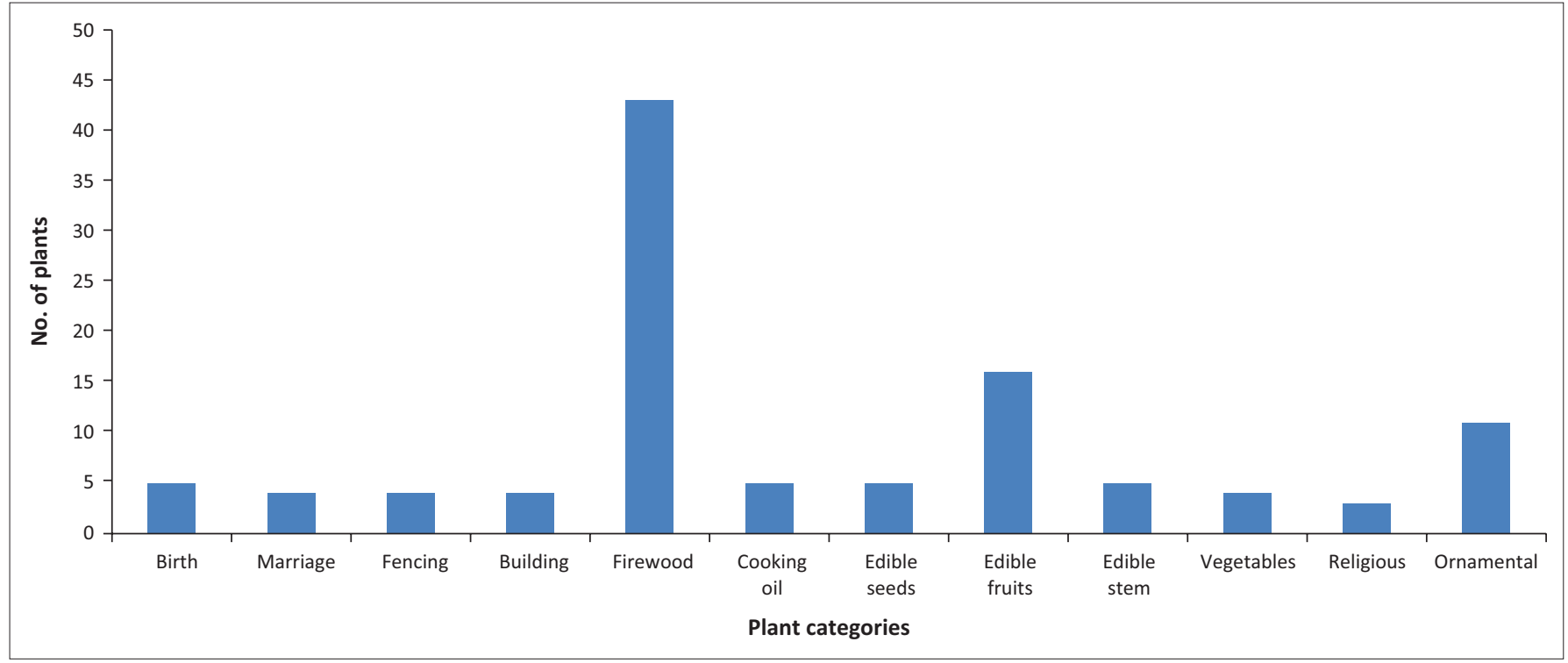

FIGURE 3: Economic uses of Otuo plants.

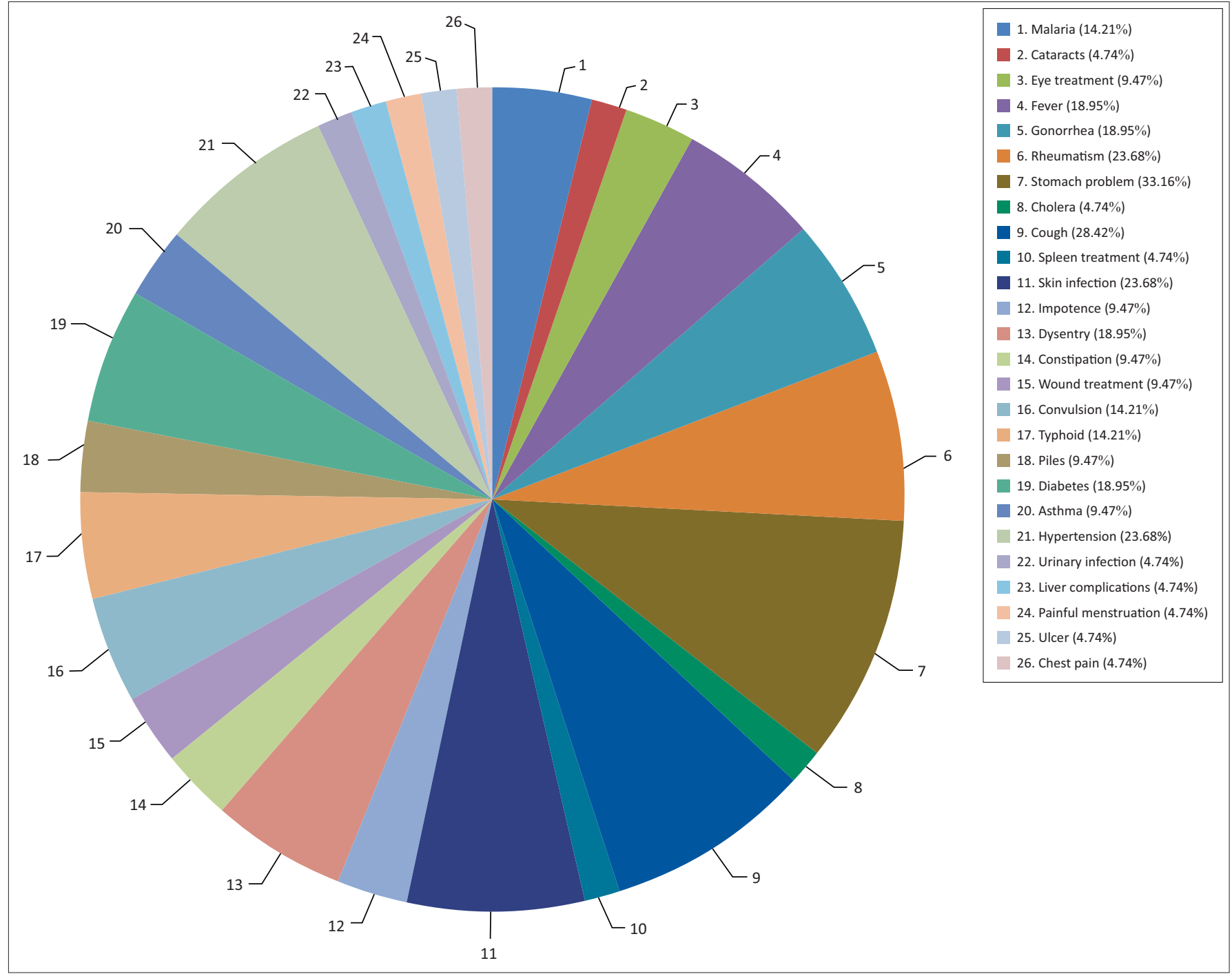

FIGURE 4: The major ailments treated with plant species in Otuo, Owan East Local Government Area. 


\section{Conclusion}

Otuo tribe has a rich cultural heritage and the people are knowledgeable about the use of countless plants found in their community. The 101 plants surveyed in this study are all medicinal with steady quotation frequencies, FLs and IVs. It is imperative that this knowledge, which is mostly passed by word of mouth from generation to generation, should be adequately documented for referral purposes.

\section{Acknowledgements}

The authors wish to thank Mr Miracle for his assistance at the study site. They also appreciate Dr Erhabor for his assistance in providing materials and guidance to put this work together.

\section{Competing interests}

The authors declare that they have no financial or personal relationships that may have inappropriately influenced them in writing this article.

\section{Authors' contributions}

M.I. designed this study and gave directions for its implementation. O.-U.O. helped to organise the results, proofread the draft of the article and put it in the journal format. I.-O.O.S. gathered field information and wrote the first draft of this article.

\section{References}

Ainslie, J.R., 1937, A list of plants used in native medicine in Nigeria, Institute Pape No. 7, Imperial Forestry Institute, University of Oxford.

Akpata, L., 1979, 'The practices of herbalism in Nigeria', in A. Sofowora (ed.), African medicinal plants, pp. 13-20, University of Ife Press, Ile-Ife.Nigeria.
Ariba, A.J., Oladipo, O.T., Iyaniwura, C.A.\& Dada, O.A., 2007, 'Management of Erectile dysfunction: Perception and practices of Nigerian primary care clinicians', South African Family Practices 49, 16a-16d. https://doi.org/10.1080/20786204.2007.10 873632

Ayensu, E.S., 1978, Medicinal plants of West Africa, Reference Publication Incoporated, Algonac, Michigan

Cotton, C.M., 1996, Ethnobotany: Principles and applications, Wiley, New York.

Enwereji, E., 1999, 'Views on tuberculosis among the Igbos of Nigeria', Indigenous Knowledge and Development Monitor 72, 3-5.

Gill, L.S., 1992, Ethnomedicinal uses of plants in Nigeria, University of Benin Press, Benin City, Nigeria.

Gill, L.S. \& Opara, C.N., 1988, 'Nigerian folk medicine: Practices and beliefs of the Igbo people', Nigerian Journal of Applied Science 6, 77-89.

Hoffman, B. \& Gallaher, T., 2007, 'Importance indices in ethnobotany', Ethnobotany Research and Applications 5, 201-218. https://doi.org/10.17348/era.5.0.201218

Idu, M., Gill, L.S., Omonhinmin, C.A.\& Ejale, A., 2006, 'Ethnomedicinal uses of trees among the Bachama tribe of Adamawa State, Nigeria', Indian Journal of Traditiona Knowledge 5, 273-278.

Idu, M. \& Olorunfemi, D.I., 2000, 'Plants used for medicinal purposes by the Koma people of Adamawa State, Nigeria', Indigenous Knowledge Monitor $8,18$.

Idu, M. \& Omoruyi, O.M., 2003, 'Some ethnomedicinal plants of Higgi tribe from Adamawa State, Nigeria', Ethnobotany 15, 48-50.

Idu, M., Onyibe, H.I., Timothy, O.\& Erhabor, J.O., 2008, 'Ethnomedicinal flora of Otuo people of Edo State, Nigeria', Asian Journal of Plant Sciences 7, 8-12. https://doi. org/10.3923/ajps.2008.8.12

Lambo, J.O., 1979, 'The healing power of herbs with special reference to obstetrics and gynaecology', in A. Sofowora (ed.), African medicinal plants, University of Ibadan Press, Nigeria.

Mume, J.O., 1976, Tradomedicalism, Jom Nature Cure Centre, Agbaro, Nigeria.

Ogbor, D.N., 1989, Folk medicinal plants: Practices and beliefs of Bini people (Oredo Local Government Area) Edo State, University of Benin, Nigeria.

Oseni, A.M., 1989, 'Botany in the production of food and drugs', key note address to the Third Annual Conference of the Botanical Society of Nigeria, University of Lagos.

Sofowora, A., 1982, Medicinal plants and traditional medicine in Africa, Wiley Chichester, West Sussex.

Sofowora, A., 1986, The state of medicinal plants research in Nigeria, University Press, Ibadan, Nigerian.

Sofowora, A., 1993, Medicinal plants and traditional medicine in Africa, Spectrum Books Limited, Ibadan 